\section{Combining demographic and land-use dynamics with local communities perceptions for analyzing socio-ecological systems: a case study in a mountain area of Italy}

\section{Andrea Pisanelli, Francesca Chiocchini, Lucia Cherubini, Marco Lauteri}

Rural communities are facing increasing social heterogeneity and organization complexity consequently to land use changes, demographic dynamics and globalization processes. Members of the communities should have a direct perception of their own territories, recognizing any positive or negative change that may occur. A better knowledge of these processes may be achieved by investigating local community awareness and perspectives. A research was carried out in a rural and mountainous area of Central Italy with the following aims: (i) to highlight demographic dynamics and land use changes that affected the area during the last decades; (ii) to assess local communities' perceptions and awareness of their own territories; (iii) to verify and validate a research methodology by evaluating the resilience of socio-ecological systems. The study area involved four municipalities that were analyzed considering the historical changes of demographic data and land-use system. A questionnaire was submitted to a sample of local population. The questionnaire was aimed to investigate the following issues: (i) level and quality of participation and communication within the community life; (ii) awareness of environmental resources of the territories; (iii) socio-cultural opportunities and expectations of future changes within the communities. In each municipality, different behaviors and needs emerged according to the age of the inhabitants. In spite of that, awareness of social, cultural and environmental constraints/potentialities emerged in all the communities. Communication capability seems a key factor to reinforce both the social capital and the resilience of the territories. Thus, sharing of experience and knowledge could play a major role in developing an efficient governance of the occurring territorial changes. Finally, the study highlights that serious efforts should be spent especially to satisfy expectations of young people concerning the territorial development. This latter seems a prerequisite for the maintenance of the system resilience.

Keywords: Participatory Governance, Social Capital, Social Survey, Rural Areas, Resilience

\section{Introduction}

Sustainable management of mountainous and rural areas deals with both ecological and socio-economic components of the territories. Several international summits and agreements (the Rio Declaration on Environment and Development 1992, the Millennium Development Goals and the Strategy of Lisbon 2000) have remarked that development policies must link economic growth and social welfare with conservation and sustainable utilization of natural resources.

Nowadays the economic importance of agricultural sector is declining in Western Europe. Over the last 20 years, rural lands have been losing their traditional production-based economic importance and have completed their transition from an agrarian economy to a modern industrial or services economy. On the other side, there has been a contemporaneous increase of both environmental and socio-cultural values, associated to the rural landscape (Slee 2007). During this shift, rural districts have been affected by the combined effect of land use changes, demographic dynamics and globalization processes (Terluin 2003). It is striking, at present, that livelihood for rural populations is not linked to agricultural and forestry resources. The increasing development of nonagricultural activities have greatly contributed to the formation of new rurality in Europe (Kasimis et al. 2010). At the same time, a decline in population and a contemporaneous ageing of residents usually affect rural areas (Thissen et al. 2010). In addition, $\square$ Institute of Agro-environmental and Forest Biology, National Research Council, v. Marconi 2, I-05010, Porano (TR - Italy).

@ Andrea Pisanelli

(andrea.pisanelli@ibaf.cnr.it)

Received: Jul 27, 2011 - Accepted: Apr 24, 2012

Citation: Pisanelli A, Chiocchini F, Cherubini L, Lauteri M, 2012. Combining demographic and land-use dynamics with local communities perceptions for analysing socio-ecological systems: a case study in a mountain area of Italy. iForest 5: 163-170 [online 2012-06-25] URL:

http://www.sisef.it/ iforest/contents? id=efor0615-005

Communicated by: Paola Mairota

immigration from foreign countries is usually increasing also in remote areas. Therefore, rural communities are facing increasing social heterogeneity and organization complexity (Storey 1999).

A better knowledge of the evolution of rural areas can be achieved by investigating the local community dynamics and changes (Brunori \& Rossi 2007) and the needs and perspectives of the different social categories or groups (Pearsson \& Westholm 1994). Individuals play an effective role in sustainable development: day-by-day choices have a straight influence on the future evolution of our societies (Catenazzo et al. 2008). Moreover, humans perceive natural and social occurrences and modify their behavior on the basis of their knowledge and expectations concerning future changes (Young et al. 2006). It is therefore relevant to know the individuals' opinion about any particular aspect of their territory (problems and potential solutions) as well as their likely behavior under future hypothetical scenarios. Thus, the development of methods and tools suitable to assess how different actors perceive complex systems is necessary (Gasparino et al. 2006).

The involvement of local actors in the assessment of their territories is a fundamental requisite to implement the participatory governance of the communities. This process supports the enforcement of a territorial analysis and helps to identify lines of action that are in accordance with the needs expressed by local communities (De Meo et al. 2010). Participatory governance is increasingly emphasized as a way to constrast a range of social malaise, including social exclusion and political apathy (United Nations 2008).

The present study deals with the concept of resilience. Resilience measures the amount of change or disruption required to transform the maintenance of a system from one set of 
mutually reinforcing processes and structures to a different set of processes and structures (Anderies et al. 2004, Folke 2006, Adger 2006). Holling (1973) introduced the notion of resilience in ecology science. Several research papers have recently discussed definitions and theories of resilience (Walker et al. 2006). Under a sociological perspective, resilience measures the ability of groups and communities to cope with external stresses and disturbances as a result of social, political and environmental changes (Brand \& Jax 2007, Adger 2000).

The concept of resilience is now used in different research fields for understanding, managing and governing socio-ecological systems (Carpenter et al. 2001). Socio-ecological systems (SES) are complex systems in nature (Stockholm Resilience Center 2010). The core of SES concept refers to the assumption that human actions and social structures are integrated within the environment and its natural resources (Adger 2006). Currently, researches on resilience mainly focus on the assessment of adaptability and transformability of SES. Adaptability is the collective capacity of the human actors to influence resilience of SES. As the human actions dominate in SES, adaptability of the system is mainly a function of its social component (the individuals and groups acting to manage the system). Transformability refers to the capability to create a fundamentally new system when previous ecological, economic, or social (including political) conditions make the existing system unsustainable (Walker et al. 2004).

This paper investigates four rural communities located in the Apennines mountains (central Italy) that are changing due to land use and demographic dynamics. The overall aim of the study is to assess and compare these dynamics according to the local community perceptions.

The research adopts an integrated approach. First, demographic and land use dynamics over the last decades are analyzed by means of a Geographic Information System (GIS). Second, a social survey is conducted by submitting a structured questionnaire to a sample of local populations of the four municipalities. This approach assumes that the which humans must be seen as a part of

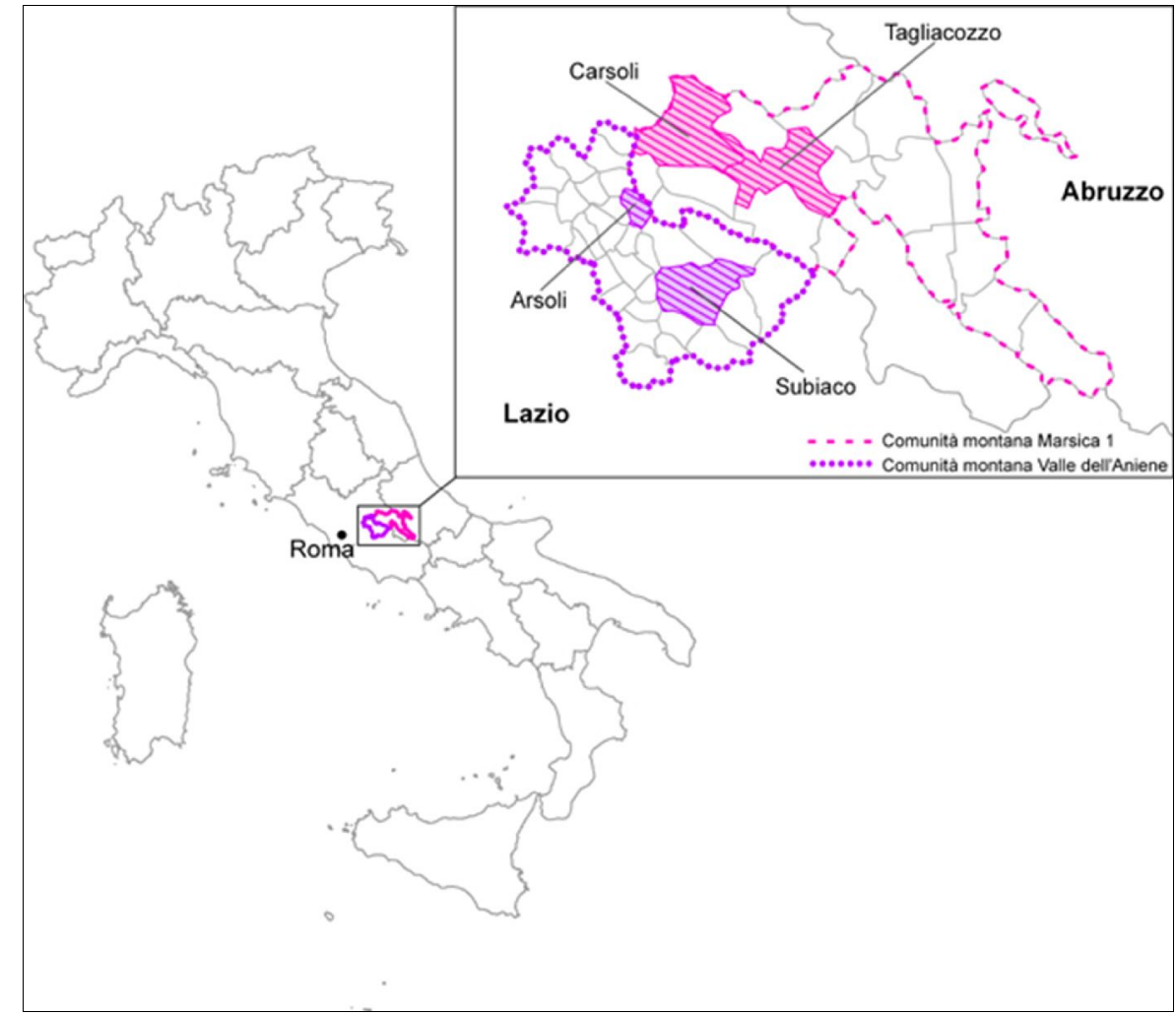

Fig. 1 - Location of the four municipalities in central Italy: Arsoli and Subiaco in Lazio Re gion (Comunità Montana Valle dell'Aniene); Carsoli and Tagliacozzo in Abruzzo Region (Comunità Montana Marsica 1).

investigation of local community perception allows understanding and interpreting the dynamics and changes of the territory where people live. Indeed, it is implied that inhabitants and members of the communities have a direct and real perception of their own territory, so that they immediately perceive any positive or negative change and modification.

The specific aims of this study are:

- to highlight demographic dynamics and land use changes that affected the territories during the last decades;

- to assess local communities' perceptions and awareness concerning some key aspects of their own territories;

- to verify and validate a research methodology by understanding and evaluating the resilience of socio-ecological systems.

Tab. 1 - Main statistical data of the four municipalities. The investigated areas are classified as mountainous territories, with altitude ranging between $326 \mathrm{~m}$ and $1737 \mathrm{~m}$ a.s.l. The data refer to the year 2001 (source: National Institute for Statistics 2009).

\begin{tabular}{lrrrc}
\hline Parameter & Arsoli & Subiaco & Carsoli & Tagliacozzo \\
\hline Territorial area (ha) & 1213 & 6344 & 9527 & 8940 \\
Inhabitants & 1537 & 9030 & 5086 & 6532 \\
Population density (inhabitants km ${ }^{-2}$ ) & 126 & 142 & 53 & 73 \\
Ageing index (national average: 142) & 192 & 162 & 155 & 206 \\
Forest area (\% of territorial area) & 22 & 45 & 43 & 26 \\
Agricultural area (\% of territorial area) & 27 & 31 & 14 & 32 \\
\hline
\end{tabular}

\section{Material and methods}

Study area, collection and analysis of statistical and spatial data

The study area involved four municipalities located in two Regions of central Italy: Arsoli and Subiaco, Lazio Region; Carsoli and Tagliacozzo, Abruzzo Region (Fig. 1). The area reflects a morphology and a landscape typical of inner and mountainous territories of central Italy. The study area in its whole is relatively close to Rome (about one hour by train or car). The city exerts a strong influence on the area, especially in terms of job opportunities, services and facilities.

The number of inhabitants living in the four municipalities ranges between 1500 (Arsoli) and 9000 (Subiaco). Population density varies from 53 (Carsoli) and 142 (Subiaco) inhabitants $\mathrm{km}^{-2}$. In all the municipalities the ageing index is higher than the national average (Tab. 1).

According to the National Institute for Statistics (2009), since the end of the World War II, depopulation phenomena interested the studied area (Fig. 2). The depopulation decreased at the beginning of ' $80 \mathrm{~s}$, when the number of inhabitants slightly increased in all the communities, and the trend is still ongoing. Carsoli recorded the highest rate of population increment, probably due to the development of the industrial sector together 


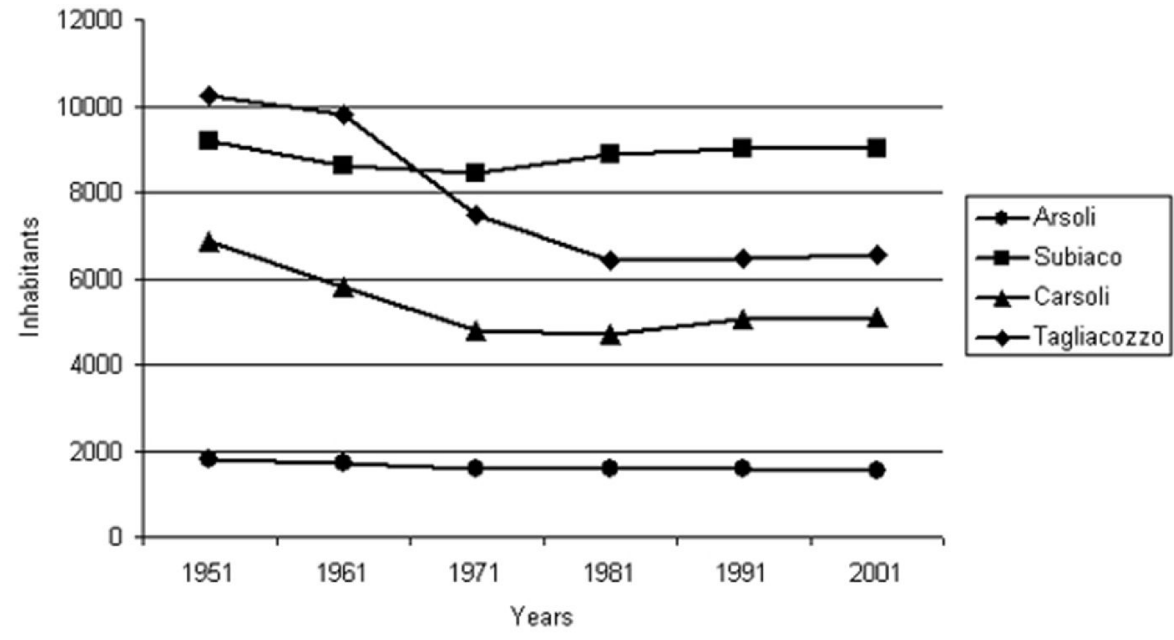

Fig. 2 - Demographic trend in the four municipalities. Following the abandonment recorded after the end of the Second World War, resident population is slightly increasing since the beginning of ' $80 \mathrm{~s}$ in all the investigated areas. Source: http://www.comuni-italiani.it

with infrastructures and transport system improvement.

The investigated territories have a natural propensity for forestry and agriculture. $\mathrm{Ne}$ vertheless, the rate of population employed in the agricultural sector is extremely limited (less than $2 \%$ of the total employed population). The agricultural system is characterized by small and fragmented farms. Ageing is affecting also agricultural sector and most of the farmers are older than 55 years (ISMEA 2010).

Statistical and spatial data of the two Comunità Montana, ${ }^{1}$ which enclose the four municipalities, were recorded in a Geographic Information System (ArcGIS, ESRI, Redlands, CA, USA) and analyzed using spatial analysis techniques.

Fig. 3 - Classification of the territories according to the indicator "territorial presidium". The indicator is obtained on the basis of the evolution of the incidence of utilised agricultural area (UAA) on the territorial area and considering the balance between immigration and emigration during the period 1990-2000. of territorial presidium were identified (Fig. 3).

Carsoli and Subiaco are classified as "areas with severe problems of abandonment". UAA and human presence declined during the period 1990-2000. Consequently, the traditional territory maintenance and management is currently under decline.

Arsoli is classified as a "rural area with low growth". A stable agricultural activity characterized this territory. Nevertheless, there was a tendency to the abandonment due to a negative balance between immigration and emigration.

Tagliacozzo is classified as a "weak rural area". UAA declined during the period 1990-2000 in this territory. Nevertheless, human presence was stable during the same period.

\section{Social survey}

A structured questionnaire was designed and submitted to a random sample of population living in the four municipalities. The questionnaire was organized in different sections dealing with the following thematic issues: Comunità Montana was analyzed considering two parameters:

- the evolution of the utilized agricultural area (UAA) during the period 1990-2000;

- the population dynamics resulting from the balance between immigration and emigration during the period 1990-2000.

Spatial analysis of these parameters allowed to estimate the "territorial presidium", according to the conceptual framework of the regional project ANCONAPACO (http:// anconapaco.regione.marche.it/ricerca.htm).

The territorial presidium was applied to estimate the human attendance to the investigated territories.

Considering the whole territories belonging to the two Comunità Montana, three classes
- general data of the respondents, such as age, gender, job, distance from working place;

- assessment of people participation within the community, in terms of quality and level of information dealing with social, cultural or political aspects; sense of belonging to the territories and potential interest in moving to other places;

- people awareness of environmental resources, considering local agroforestry products as tools for development; people perception of environmental problems and potentialities of their own territory;

- people interest in attending cultural and

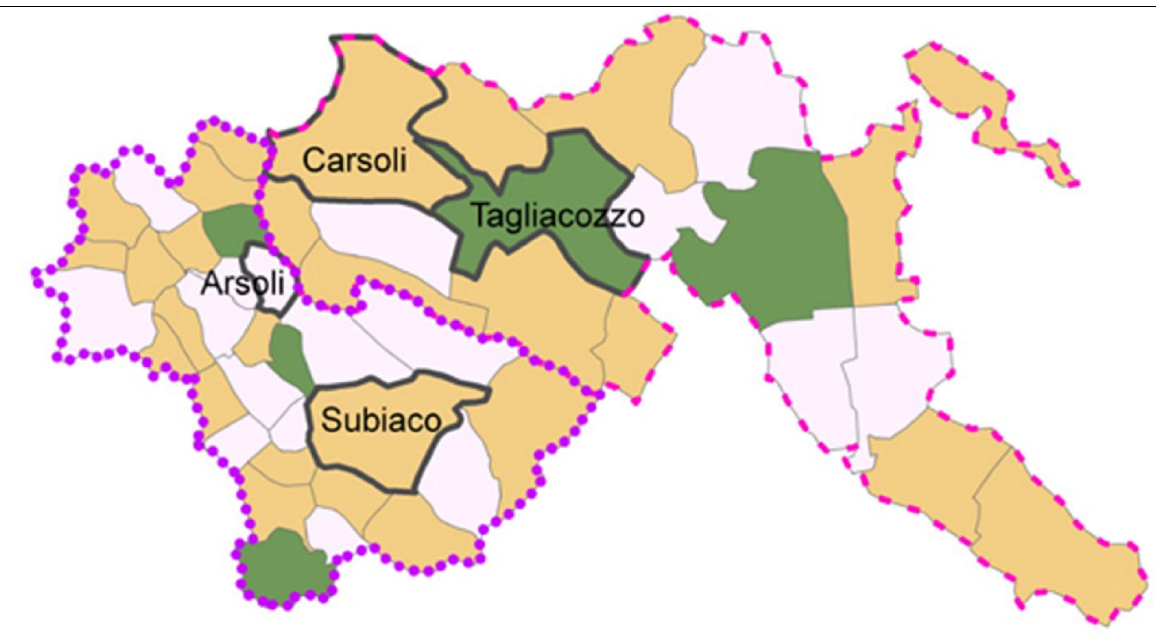

Areas with severe problems of abandonment

Weak rural areas

- - - Comunità Montana Marsica1

Rural areas with low growth 
social events organized within the territories or in adjacent areas; people perception of changes and challenges that are occurring or that are expected to occur.

The questionnaire contained both open-ended questions (qualitative data) and closeended questions (quantitative data). The respondents could answer with free sentences to the open questions; they could answer "yes", "no" or "I don't know" to the close questions. The interviews were conducted face-to-face by two local consultants during the period September-December 2009. A total amount of 402 persons were interviewed, with age ranging between 18 and 65 years.

The data were analyzed in terms of frequency of answers to each question considering both qualitative and quantitative data Two age classes were defined: between 18 and 35 years old ("young") and between 3665 years old ("adult"). One way analysis of variance (ANOVA) was performed in order to detect significant differences of responses among the four municipalities. The Student's test was also carried out in order to explore possible differences between the two age classes within each municipality. Pearson's correlation coefficient was calculated for as sessing any correlation among the variables (questions). The Principal Component Analysis (PCA) was applied to visualize differences among the municipalities and determine the key variables that explain the observed differences. All the computations were performed using NTSYS-PC version 2.1 and XLSTAT 2010 (http://www.xlstat.com) software packages.

\section{Results}

\section{Sample description}

The average age of the interviewed persons was about 39 years; $45 \%$ of the sample was between 18 and 35 years old (young) and $55 \%$ was between 36 and 65 years old (adult). Males and females represented 55\% and $45 \%$ of the sample, respectively (Tab. 2).

Most of the interviewed (60\%) had a secondary school degree and $12 \%$ were still

Tab. 2 - Description of the resident inhabitants involved in the social survey. Two local consultants interviewed a random sample of population in each municipality. Young include respondents with age between 18 and 35 years. Adult include respondents with age between 36 and 65 years.

\begin{tabular}{lccccc}
\hline Parameters & Arsoli & Subiaco & Carsoli & Tagliacozzo & Overall \\
\hline No. of Respondents & 100 & 100 & 102 & 100 & 402 \\
Male (\%) & 55 & 52 & 42 & 72 & 55 \\
Female (\%) & 45 & 48 & 58 & 28 & 45 \\
Average age (years) & 36 & 41 & 37 & 41 & 39 \\
Young (\%) & 54 & 36 & 50 & 40 & 45 \\
Adult (\%) & 46 & 64 & 50 & 60 & 55 \\
\hline
\end{tabular}

students, with highest percentage in Tagliacozzo. Most of the respondents were employed as public dependents (teachers, public officers, medical officers) or as entrepreneurs (running their own business or private dependents). Unemployed were $5 \%$, workers were $12 \%$ with the highest values in Arsoli (22\%) and Carsoli (18\%). About $17 \%$ of the respondents commutes every day, with an average commuting distance (Rome was the most common workplace) ranging between $45 \mathrm{~km}$ (Arsoli) and $63 \mathrm{~km}$ (Subiaco). Respondents affirmed to travel at least 5 days a week, leaving home about 9-10 hours every day.

\section{People participation and communica-} tion tools

The results of the questions concerning people participation and communication tools within the local communities are reported in Tab. 3.

According to the respondents, the inhabitants get acquainted with social, cultural and political aspects of their own community by means of posters or leaflets, by local journals and by word of mouth. Internet is also quite commonly used in all the four municipalities.

About $70 \%$ of the respondents declared to be quite well-informed about the social and cultural aspects of their own community; $63 \%$ considered the level of information to be quite good across the four municipalities. Only in Tagliacozzo more than a half of the sample considered the level of information to be poor and not properly developed.

According to the age of the respondents, no evident differences emerged by comparing the answers of adult and young inhabitants about the quality and level of information. Only in Subiaco young residents stated that communication and information are manifestly weak.

Considering the entire sample, $61 \%$ of the respondents felt a strong sense of belonging to the their own territories and most of them highlighted to really appreciate living there. The favorable climate and the landscape diversity, the local culture and tradition were deeply appreciated by both adult and young people. At the same time, almost half of the surveyed people had aspiration to leave the area where they live, with the highest percentage recorded in Tagliacozzo $(62 \%)$ and the lowest in Subiaco (32\%). The main reasons to move were: the ambition to improve the job position; the need to implement social and cultural activities; and, generally, the expectation of better opportunities. On the contrary, those not intentioned to move away showed to appreciate their territory mainly for the life quality.

The interest to move away was stronger in young than in adult respondents: overall, the proportion of respondents willing to move away was $71 \%$ and $29 \%$ for young adult people, respectively. This finding was particularly evident in Tagliacozzo, where more than $90 \%$ of the young respondents expressed the willingness to live in other places.

Tab. 3 - Participation and quality of communication assessed throughout the social survey (frequency of positive responses to each question). Young and adult categories include respondents with age between 18 and 35 years and between 36 and 65 years, respectively. Significance of ANOVA analysis between the age classes within each municipality or among the municipalities considering the total sample: $(*)$ $=\mathrm{p} \leq 0.05 ;(* *)=\mathrm{p} \leq 0.01$.

\begin{tabular}{|c|c|c|c|c|c|c|c|c|c|c|c|c|}
\hline \multirow[b]{2}{*}{ Questions } & \multicolumn{3}{|c|}{ Arsoli } & \multicolumn{3}{|c|}{ Subiaco } & \multicolumn{3}{|c|}{ Carsoli } & \multicolumn{3}{|c|}{ Tagliacozzo } \\
\hline & $\begin{array}{l}\text { Young } \\
(\mathrm{n}=54)\end{array}$ & $\begin{array}{l}\text { Adults } \\
(\mathrm{n}=46)\end{array}$ & $\begin{array}{c}\text { Total } \\
(\mathrm{n}=\mathbf{1 0 0})\end{array}$ & $\begin{array}{l}\text { Young } \\
(\mathrm{n}=36)\end{array}$ & $\begin{array}{l}\text { Adults } \\
(\mathrm{n}=64)\end{array}$ & $\begin{array}{c}\text { Total } \\
(\mathbf{n}=\mathbf{1 0 0})\end{array}$ & $\begin{array}{l}\text { Young } \\
(\mathrm{n}=51)\end{array}$ & $\begin{array}{l}\text { Adults } \\
(\mathrm{n}=51)\end{array}$ & $\begin{array}{c}\text { Total } \\
(\mathrm{n}=\mathbf{1 0 2})\end{array}$ & $\begin{array}{l}\text { Young } \\
(\mathrm{n}=40)\end{array}$ & $\begin{array}{l}\text { Adults } \\
(\mathrm{n}=60)\end{array}$ & $\begin{array}{c}\text { Total } \\
(\mathbf{n}=100)\end{array}$ \\
\hline Enough informed & 0.81 & 0.78 & 0.80 & $0.61^{* *}$ & 0.88 & 0.78 & 0.71 & 0.78 & 0.75 & 0.45 & 0.52 & $0.49^{* *}$ \\
\hline Good level of communication & 0.76 & 0.63 & 0.70 & 0.72 & 0.72 & 0.72 & 0.67 & 0.71 & 0.69 & 0.53 & 0.37 & $0.43^{* *}$ \\
\hline $\begin{array}{l}\text { Strong identification with the } \\
\text { territory }\end{array}$ & 0.56 & 0.65 & 0.60 & $0.33^{* *}$ & 0.86 & 0.67 & $0.37^{* *}$ & 0.69 & 0.53 & 0.50 & 0.73 & 0.64 \\
\hline $\begin{array}{l}\text { Interested to move to other } \\
\text { places }\end{array}$ & $0.67^{* *}$ & 0.35 & 0.52 & $0.67^{* *}$ & 0.13 & $0.32^{* *}$ & $0.63^{* *}$ & 0.31 & 0.47 & $0.93^{* *}$ & 0.42 & $0.62^{* *}$ \\
\hline
\end{tabular}


Tab. 4 - Awareness of environmental resources assessed throughout the social survey (frequency of positive responses to each question). Young and adult categories include respondents with age between 18 and 35 years and between 36 and 65 years, respectively. Significance of ANOVA analysis between the age classes within each municipality or among the municipalities considering the total sample: $(*)=$ $\mathrm{p} \leq 0.05 ;(* *)=\mathrm{p} \leq 0.01$

\begin{tabular}{|c|c|c|c|c|c|c|c|c|c|c|c|c|}
\hline \multirow[b]{2}{*}{ Questions } & \multicolumn{3}{|c|}{ Arsoli } & \multicolumn{3}{|c|}{ Subiaco } & \multicolumn{3}{|c|}{ Carsoli } & \multicolumn{3}{|c|}{ Tagliacozzo } \\
\hline & $\begin{array}{l}\text { Young } \\
(\mathrm{n}=54)\end{array}$ & $\begin{array}{l}\text { Adults } \\
(\mathrm{n}=46)\end{array}$ & $\begin{array}{c}\text { Total } \\
(\mathrm{n}=100)\end{array}$ & $\begin{array}{l}\text { Young } \\
(\mathrm{n}=36)\end{array}$ & $\begin{array}{l}\text { Adults } \\
(\mathrm{n}=64)\end{array}$ & $\begin{array}{c}\text { Total } \\
(\mathrm{n}=\mathbf{1 0 0})\end{array}$ & $\begin{array}{l}\text { Young } \\
(\mathrm{n}=51)\end{array}$ & $\begin{array}{l}\text { Adults } \\
(\mathrm{n}=51)\end{array}$ & $\begin{array}{c}\text { Total } \\
(\mathrm{n}=\mathbf{1 0 2})\end{array}$ & $\begin{array}{l}\text { Young } \\
(\mathrm{n}=40)\end{array}$ & $\begin{array}{l}\text { Adults } \\
(\mathrm{n}=60)\end{array}$ & $\begin{array}{c}\text { Total } \\
(n=100)\end{array}$ \\
\hline $\begin{array}{l}\text { Knowledge of organic } \\
\text { products }\end{array}$ & 0.85 & 0.91 & 0.88 & $0.75^{* *}$ & 0.95 & 0.88 & 0.86 & 0.86 & 0.86 & $0.55^{* *}$ & 0.87 & 0.74 \\
\hline $\begin{array}{l}\text { Typical products as a } \\
\text { development tool }\end{array}$ & 0.81 & 0.89 & 0.85 & 0.83 & 0.89 & 0.87 & 0.76 & 0.76 & $0.76^{* *}$ & 0.98 & 0.98 & $0.98^{* *}$ \\
\hline $\begin{array}{l}\text { Possibility to buy typical } \\
\text { products }\end{array}$ & 0.56 & 0.50 & 0.53 & 0.78 & 0.81 & $0.80^{* *}$ & 0.24 & 0.33 & $0.28^{* *}$ & 0.98 & 0.98 & $0.98^{* *}$ \\
\hline $\begin{array}{l}\text { Existence of environmental } \\
\text { problems in the territory }\end{array}$ & 0.43 & 0.33 & 0.38 & 0.58 & 0.41 & 0.47 & 0.47 & 0.47 & 0.47 & $0.45^{*}$ & 0.72 & $0.61^{* *}$ \\
\hline
\end{tabular}

\section{Awareness of environmental resources}

The results of the questions concerning local community awareness of environmental resources are reported in Tab. 4.

Most of the interviewed people showed great awareness and appreciation about the environmental value of their territory. Forests, mountains, natural parks, natural caves, and water resources such as lakes and rivers were the most appreciated natural resources of the territories. Nevertheless, $48 \%$ of the respondents affirmed that this natural richness is threatened by several constraints. Arsoli inhabitants, for example, affirmed that a quarry represents a major environmental problem, while residents in Subiaco often complained about the abundant waste presence along the river. In all the communities most of the respondents perceived urban wastes as a relevant problem. Usually, people addressed to the public authorities the responsibility of solving the situation, claiming for the adoption of appropriate measures (e.g., waste differentiation and recycling of urban wastes).

High quality goods, such as local agroforestry products or organic and typical foods, are commonly considered as an expression of specific or unique environmental conditions, characterizing the uncontaminated but often marginal mountain landscapes. In all the communities these goods are considered to be a powerful tool to promote rural development, especially by stimulating rural tourism. Nevertheless, the possibility to buy these products, according to their market accessibility, was perceived contrastingly among the four communities.

\section{Cultural interests and perception of fu-} ture changes

The results of the questions related to inhabitants' cultural interests and to people perception of future changes are reported in Tab. 5.

In all the communities, people participation in cultural and social events, usually organized by local authorities or private organizations and associations, is usually very large. A percentage of about $86 \%$ of all the respondents affirmed that they regularly attend these events, with the highest value in Tagliacozzo and the lowest in Subiaco. According to the interviews, local parties (called sagra), usually organized in public squares or in green areas, resulted to be the most common and popular cultural events in all the communities. For example, in Arsoli the Sagra della Fagiolina Arsolana, a local variety of bean, is very popular (Lauteri et al. 2007).

In Tagliacozzo, the respondents declared to appreciate various cultural events regularly organized. For instance, the Festival of Cinema and the Midsummer Festival represent happenings of national and international relevance. Moreover, in Tagliacozzo other particular events are related to organic food. On these occasions interested people can acquire knowledge, get information and taste organic products. Thus, the survey highlighted different levels of cultural consumes among the four municipalities, with a greater cultural offer in Tagliacozzo.

Most of the respondents, especially in Tagliacozzo, were also informed about events organized in the neighboring areas. In particular, young people were interested to attend such events.

Within all the communities, most of the respondents claimed that attending cultural events is relatively expensive; however, most of them declared their willingness to participate in highly interesting events when organized.

Finally, the questionnaire investigated the perceived or wished challenges, occurring or

Tab. 5 - Assessment of cultural interest and perception of future changes throughout the social survey (frequency of positive responses to each question). Young and adult categories include respondents with age between 18 and 35 years and between 36 and 65 years, respectively. Significance of ANOVA analysis between the age classes within each municipality or among the municipalities considering the total sample: $(*)=p \leq 0.05 ;(* *)=p \leq 0.01$.

\begin{tabular}{|c|c|c|c|c|c|c|c|c|c|c|c|c|}
\hline \multirow[b]{2}{*}{ Questions } & \multicolumn{3}{|c|}{ Arsoli } & \multicolumn{3}{|c|}{ Subiaco } & \multicolumn{3}{|c|}{ Carsoli } & \multicolumn{3}{|c|}{ Tagliacozzo } \\
\hline & $\begin{array}{l}\text { Young } \\
(\mathrm{n}=54)\end{array}$ & $\begin{array}{l}\text { Adults } \\
(\mathrm{n}=46)\end{array}$ & $\begin{array}{c}\text { Total } \\
(\mathrm{n}=100)\end{array}$ & $\begin{array}{l}\text { Young } \\
(\mathbf{n}=36)\end{array}$ & $\begin{array}{l}\text { Adults } \\
(\mathrm{n}=64)\end{array}$ & $\begin{array}{c}\text { Total } \\
(n=100)\end{array}$ & $\begin{array}{l}\text { Young } \\
(\mathrm{n}=51)\end{array}$ & $\begin{array}{l}\text { Adults } \\
(\mathrm{n}=51)\end{array}$ & $\begin{array}{c}\text { Total } \\
(n=102)\end{array}$ & $\begin{array}{l}\text { Young } \\
(\mathrm{n}=40)\end{array}$ & $\begin{array}{l}\text { Adults } \\
(\mathrm{n}=60)\end{array}$ & $\begin{array}{c}\text { Total } \\
(\mathrm{n}=100)\end{array}$ \\
\hline $\begin{array}{l}\text { Participation in cultural events } \\
\text { in the community }\end{array}$ & 0.91 & 0.80 & 0.86 & 0.78 & 0.67 & $0.71^{*}$ & 0.84 & 0.94 & 0.89 & 1.0 & 0.98 & $0.99^{* *}$ \\
\hline $\begin{array}{l}\text { Economic incidence of cultural } \\
\text { activities }\end{array}$ & 0.81 & 0.63 & 0.73 & 0.89 & 0.66 & 0.74 & $1.0^{* *}$ & 0.69 & 0.84 & $0.93^{* *}$ & 0.58 & 0.72 \\
\hline $\begin{array}{l}\text { Interest in increasing expenses } \\
\text { for cultural activities }\end{array}$ & 0.69 & 0.72 & 0.70 & 0.83 & 0.86 & 0.85 & 0.82 & 0.69 & 0.75 & $0.85^{*}$ & 0.60 & 0.70 \\
\hline $\begin{array}{l}\text { Perception of the need of } \\
\text { challenges in the community }\end{array}$ & 0.30 & 0.26 & 0.28 & 0.22 & 0.13 & 0.16 & 0.27 & 0.27 & 0.27 & 0.43 & 0.62 & $0.54^{* *}$ \\
\hline
\end{tabular}


expected to occur within the community Only one third of all the respondents perceived the need of challenges, with the exception of Tagliacozzo, where this perception appeared to be stronger than in the other municipalities. The expected challenges should be mainly addressed to promote a better use of natural resources, to increase job opportunities and to organize meeting points and events for young people.

\section{Discussion}

The retrospective analysis of the evolution of both demography and land use system highlights the changes affecting the investigated areas during the last decades. The communities shifted from an economic system based on traditional and extensive agrosilvo-pastoral practices to a modern society constituted by a growing heterogeneity of residents. Environmental constraints (such as steep and rocky uplands, poor and shallow soils) often represent insurmountable obstacles for the adoption of modern agricultural practices. The socio-economic profiles of the communities denotes a progressive ageing of the population and a growing difficulty for young generations to satisfy their needs. Al these factors displace the investigated rura areas towards marginality with striking abandonment phenomena: according to Pinto Correia (1993) in marginal lands productivity level is situated close to the margin beyond which management expenses and risks are not compensated by the profit obtained with production.

The social survey highlighted that in all the communities the young people denote a lower integration and sense of belonging to the territory than the adult residents. It seems that young generations are losing the awareness of traditional culture and knowledge. Their feeling with their own territories appears to be contrasting: they appreciate and perceive the value of the natural environment, but they also denounce the lack of infrastructures and opportunities. These find ings appear to be in agreement with other studies showing that the idyllic aspects of rural life often co-exist with the image of rural dull (Rye 2006). In other words, young people associate the concept of rurality with those of boredom and lack of opportunities.

The general strong interest in attending socio-cultural activities highlights the need to implement appropriate events, suitable to create a favorable conditions for sharing cultural experiences. These events should be primarily attractive for young people, as they manifest a great need to satisfy their cultural interests.

Local inhabitants manifest great awareness of use and management of natural resources. Thus, they strongly require the adoption of innovative, environmental-friend technologies in agriculture. The management of agri- cultural lands should favor, for example, a better organization of the whole chain of local agroforestry products, by promoting their cultivation within the local farming system and by facilitating their market visibility and accessibility in order to match the increasing demand of eco-tourism.

The quality of communication and information appears to be weaker in Tagliacozzo than in the other investigated territories. Despite this evidence, the respondents living in Tagliacozzo have the highest level of education and cultural interests. This suggests a relatively greater level of awareness of Tagliacozzo inhabitants concerning their own territory. Such a consciousness likely stimulates the observed criticism regarding local information and management. Furthermore, the same consciousness can explain why a high percentage of respondents at Tagliacozzo wishes or perceives challenges at local level. This also supports the fact that most of the interviewed people aims to move away. This appears to confirm that highly educated people are prone to leave rural areas (Thissen et al. 2010). Moreover, according to Kasimis et al. (2010) the improvement of education level and life standard increased youngs' expectations. Consequently, young generations often intend to look for alternative opportunities outside the marginality of the studied rural areas.

This study deals with the concept of resilience. The participative approach adopted in this research may contribute to identify a strategy for reinforcing the adaptability of socio-ecological systems. Indeed, economic constraint is recognized to be the driving factor for the decline of rural areas, whereas a sense of belonging to the communities and a strong social participation can mitigate such decline (McManus et al. 2012).

Finally, this study deals with the management of the territory and refers to its governance. The territorial governance is the ability of public and private stakeholders to build consensus and to define common objectives and tasks (Davoudi et al. 2008). Any action or change aiming to promote rural development should take into account primarily the needs of each group and actor representing the social capital of the communities (Magnani \& Struffi 2009). The social capital is emerging as a fundamental tool for understanding the engendering of change. There is general consensus that strengthening social capital may increase the system resilience, although this relation is often highly complex (Wolf et al. 2010). On the other side, any weakness of the social capital may explain why change does not occur in the community (Rydin \& Holman 2004) and why any new effort to pursue economic and social development is lacking (Zekeri 1994). In this sense, the analysis of community perception and perspective may contribute to assess the level of adaptive capacity of the communities (Smit \& Wandel 2006) and to achieve an effective collaborative management. At present, such an approach appears fundamental for the governance of endangered socio-ecological systems (Plummer \& Armitage 2007).

\section{Conclusions}

The paper aims to provide a tool to read and dynamically interpret the changes occurring in marginal socio-ecological systems. Recently, social and economic globalization has determined an increased flows of goods, resources, people, information and ideas all over the world. In western European countries, this process has induced rapid social and economic changes. Besides urban areas, such pressures affect also marginal rural communities.

The social survey carried out in this research demonstrated that local inhabitants are aware of their own territories in terms of social, cultural and environmental constraints and potentialities. The small dimension of the communities facilitates effective and soundly social relationships among groups and individuals. The sharing of information and knowledge among the actors of the communities reinforces the social capital of the territories. In fact, the results presented here showed that communities equipped with communication capability have also a greater level of information and knowledge concerning their own territories.

The adaptability of the socio-ecological system is mainly a function of the social components of the system (Walker et al. 2004). Thus, in order to manage desired system changes, it is fundamental to create favorable conditions for sharing of experiences and knowledge among inhabitants.

Local residents of the four investigated municipalities recognize the high value of the territories where they live. In particular, natural resources represent the main richness of the territories and local people strongly require appropriate and sustainable environmental management. Inhabitants recognize also the cultural value of the territories, as well as the local and popular traditions.

However, inhabitants perceive that this great value is threatened by several constraints mainly due to a weak management of the territories: abandonment of traditional agroforestry practices, lack of green areas, waste dispersal, increasing pollution and environmental degradation.

Young residents manifest great expectations in terms of social spaces, better use of natural resources and, particularly, job opportunities. The lack of political reaction to these main questions could determine, in a near future, severe consequences of abandonment, reduction of territorial maintenance, loss of traditional cultures and know- 
ledge. All this has the potential to depress the resilience of the analysed socio-ecological systems.

Finally, it is expected that the implementation of such kind of studies may furnish the basic knowledge for promoting an effective territorial governance. This latter would rely on the capacity to create consensus, common objectives and strategies among the different actors of the territorial dynamics

\section{Acknowledgments}

The research was supported by the Consorzio Universitario per la Ricerca Socioeconomica e per l'Ambiente (CURSA) in the framework of the project: Sperimentazione di azioni innovative e attività di comunicazione e promozione nel campo della biodiversità in aree montane marginali, funded by the Italian Ministry for the Environment. The authors are in debt with the project coordinator, Dr. Stefano Banini, Prof. Giuseppe Scarascia Mugnozza for his convinced support to the study, and with the local consultants Mr. Emanuele Piacentini and Mr. Alessio Buzzelli, who successfully conducted the interviews in the four municipalities. Acknowledgments are also due to Mrs. Emanuela Appodia and Dr. Marco Alimonti for their helpful suggestions and discussions on the work. Dr. Mario Iacomini is acknowledged for stimulating discussions and criticisms about the study. Finally, the authors wish to thank Dr. Paola Pollegioni for her substantial inputs in the statistic data analysis.

\section{References}

Adger WN (2000). Social and ecological resilience: are they related? Progress in Human Geography 24: 347-364. - doi: 10.1191/0309132 00701540465

Adger WN (2006). Vulnerability. Global Environmental Change 16: 268-281. - doi: 10.1016/j.gloenvcha.2006.02.006

Anderies JM, Jansen MA, Ostrom E (2004). A framework to analyze the robustness of social-ecological systems from an institutional perspective. Ecology and Society 9 (1): 18. [online] URL:

http://www.ecologyandsociety.org/vol9/iss1/art1 8

Brand FS, Jax K (2007). Focusing the meaning(s) of resilience: resilience as a descriptive concept and a boundary object. Ecology and Society 12 (1): 23. [online] URL: http://www.ecologyandsociety.org/vol12/iss1/art23/

Brunori G, Rossi A (2007). Differentiating countryside: social representations and governance patterns in ryural ares with high social density: the case of Chianti, Italy. Journal of Rural Studies 23: 183-205. - doi: 10.1016/j.jrurstud.2006. 10.001

Carpenter S, Walker B, Anderies JM, Abel N (2001). From metaphor to measurement: resilience of what to what? Ecosystems 4: 765-781. - doi: 10.1007/s10021-001-0045-9

Catenazzo G, D’Urso J, Fragnière E (2008). Elements of perception regarding sustainable development in Geneva. CRAG - Haute Ecole de Gestion de Genève. [online] URL: http://ssrn.com/abstract $=1301551$.

De Meo I, Ferretti F, Cantiani MG, Cantiani P (2010). Participation processes to support forest planning: a study case in southern Italy. Proceedings of the Workshop on decision support systems in sustainable forest management. Lisbon (Portugal) April 2010. [online] URL: http://www.fc.ul.pt/dsfm2010/docs/posters/paper 50.pdf

Davoudi S, Evans N, Governa F, Santangelo M (2008). Territorial governance in the making. Approaches, methodologies, practices. Boletìn de la Asociación de Geógrafos Españoles 46: 351-355. [online] URL: http://age.ieg.csic.es/ boletin.htm.

Folke C (2006). Resilience: the emergence of a perspective for social-ecological systems analyses. Global Environmental Change 16: 253267. - doi: 10.1016/j.gloenvcha.2006.04.002

Gasparino U, Del Corpo B, Pinelli D (2006). Perceived diversity of complex environmental systems: multidimensional measurement and synthetic indicators. Nota di lavoro 49/2006, Fondazione Enrico Mattei, Milan, Italy. [online] URL: http://www.feem.it/

Holling CS (1973). Resilience and stability of ecological systems. Annual Review of Ecology and Systematics 4: 1-23. - doi: 10.1146/annurev.es.04.110173.000245

ISMEA (2010). Rete Rurale Nazionale 20072013. Istituto di Servizi per il Mercato Agricolo Alimentare, Rome, Italy. [online] URL: http://www.reterurale.it.

Kasimis C, Papadopoulos AG, Pappas C (2010). Gaining from rural migrants: migrant employment strategies and socio-economic implication for rural labour markets. Sociologia Ruralis 50 (3): 258-276. - doi: 10.1111/j.1467-9523.2010. 00515.x

Lauteri M, Alimonti M, Oriani A, Pisanelli A (2007). Cambiamenti climatici, processi di abbandono, conservazione e sviluppo in paesaggi marginali Mediterranei. In: "Clima e cambiamenti climatici: le attività di ricerca del CNR" (Carli B, Cavarretta M, Colacino M, Fuzzi S eds). Consiglio Nazionale delle Ricerche, Roma, Italia, pp. 761-764.

Magnani N, Struffi L (2009). Translation sociology and social capital in rural development initiatives. A case study from Italian Alps. Journal of Rural Studies 25: 231-238. - doi: 10.1016/ j.jrurstud.2008.10.004

McManus P, Walmsley J, Argent N, Baum S, Bourke L, Martin J, Pritchard B, Sorensen T (2012). Rural community and rural resilience: what is important to farmers in keeping their country towns alive? Journal of Rural Studies 28: 20-29. - doi: 10.1016/j.jrurstud.2011.09.003

National Institute for Statistics (2009). Atlante statistico dei Comuni. National Institute of Statistics, [online] URL: http://www3.istat.it/dati/ catalogo/20061102_00/

Pearsson LO, Westholm E (1994). Towards the new mosaic of rural regions. European Review of Agricultural Economics 21 (3-4): 409-427. doi: 10.1093/erae/21.3-4.409

Pinto Correia T (1993). Land abandonment: changes in the land use patterns around the Mediterranean basin. Options Méditerranéennes 1 (2): 97-112.

Plummer R, Armitage D (2007). A resilience-based framework for evaluating adaptive co-management: linking ecology, economics and society in a complex world. Ecological Economics 61: 62-74. - doi: 10.1016/j.ecolecon.2006. 09.025

Rye JF (2006). Rural youths' images of the rural. Journal of Rural Studies 22: 409-421. - doi: 10.1016/j.jrurstud.2006.01.005

Rydin Y, Holman N (2004). Re-evaluating the contribution of social capital in achieving sustainable development. Local Environment 9: 1733. - doi: 10.1080/1354983042000199561

Slee B (2007). Social indicators of multifunctional rural land use: the case of forestry in the UK. Agricultural, Ecosystems and Environment 120: 31 40. - doi: 10.1016/j.agee.2006.03.034

Smit B, Wandel J (2006). Adaptation, adaptive capacity and vulnerability. Global Environmental Change 16: 282-292. - doi: 10.1016/j.gloenvcha.2006.03.008

Stockholm Resilience Center (2010). Resilience dictionary. Web Site. [online] URL: http://www. stockholmresilience.org

Storey D (1999). Issues of integration, participation and empowerment in rural development: the case of Leader in the Republic of Ireland. Journal of rural studies 15: 307-315. - doi: 10.1016/ S0743-0167(98)00073-4

Terluin IJ (2003). Differences in economic development in rural regions of advanced countries: an overview and critical analysis of theories. Journal of Rural Studies 19: 327-344. - doi: 10.1016/S0743-0167(02)00071-2

Thissen F, Fortuijn JD, Strijker D, Haartsen T (2010). Migration intention of rural youth in the Westhoek, Flanders, Belgium and Veenkoloniën, The Netherlands. Journal of Rural Studies 26 : 428-436. - doi: 10.1016/j.jrurstud.2010.05.001

United Nations (2008). Participatory governance and the Millennium Development Goals (MDGs). [online] URL: http://unpan1.un.org/intradoc/groups/public/documents/un/unpan028359.pdf.

Walker B, Holling CS, Carpenter SR, Kizing A (2004). Resilience, adaptability and transformability in social-ecological systems. Ecology and Society 9 (2): 5. [online] URL: http://www.ecologyandsociety.org/vol9/iss2/art5/.

Walker B, Anderies JM, Kinzig AP, Ryan P (2006). Exploring resilience in social-ecological systems through comparative studies and theory development: introduction to the special issue. Ecology and Society 11 (1): 12. [online] URL: http://www.ecologyandsociety.org/vol11/iss1/art $12 /$

Wolf J, Adger WN, Lorenzoni I, Abrahamson V, 
Raine R (2010). Social capital, individual responses to heat waves and climate change adaptation: an empirical study of two UK cities. Global Environmental Change 20: 44-52. - doi: 10.1016/j.gloenvcha.2009.09.004

Young OR, Berkhout F, Gallopin GC, Janssen MA, Ostrom E, van der Leeuw S (2006). The globalization of socio-ecological systems: An agenda for scientific research. Global Environmental Change 16: 304-316. - doi: 10.1016/j.gloenvcha.2006.03.004

Zekeri AA (1994). Adoption of economic development strategies in small towns and rural areas: effects of past community action. Journal of Rural Studies 10: 185-195. - doi: 10.1016/07430167(94)90029-9

\section{Notes}

1. Comunità Montana is a public authority aggregating neighboring municipalities located in mountain territories. The investigated municipalities are part of Comunità Montana Valle dell'Aniene and Comunità Montana Marsica 1. 